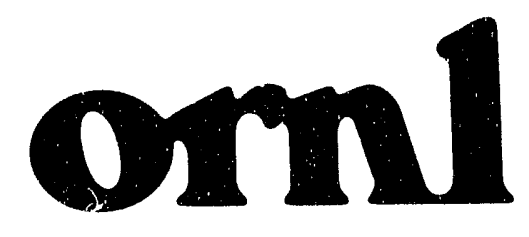

OAK RIDGE NATIONAL LABORATORY

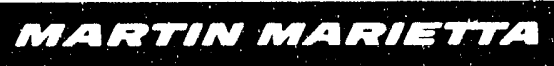

\section{An Investigation of Scramming the Outer Shutdown Rods of the ANS with No Reversal of Flow in the Manifold Inlet Lines}

\author{
Katarina Morsk \\ The Royal Institute \\ Stockholm, Sweden
}

October 1992

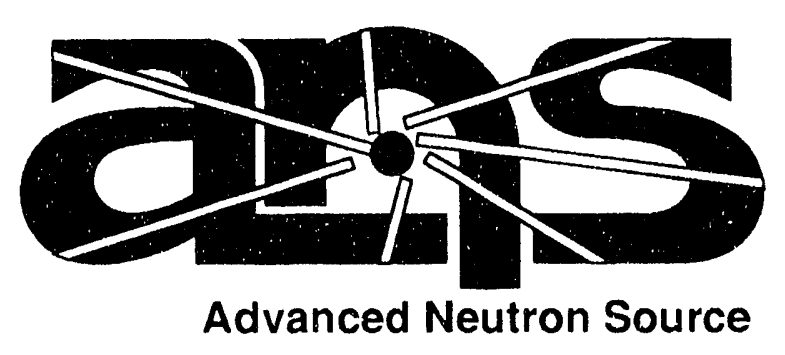


This report has been reproducied directly from the best available copy.

Available to DOE and DOE contractors from the Office of Scientific and Technical Information, P.O. Box 62, Oak Ridge, TN 37831; prices available from (615) 576-8401, FTS 626-8401.

Available to the public from the National Technical Information Service, U.S. Department of Commerce, 5285 Port Royal Rd., Springfield, VA 22161.

This report was prepared as an account of work sponsored by an agency of the United States Government. Neither the United States Government nor any agency thereof, nor any of their employees, makes any warranty, express or implied, or assumes any legal liability or responsibility for the accuracy, completeness, or usefulness of any information, apparatus, product, or process disclosed, or represents that its use would not infringe privately owned rights. Reference herein to any specific commercial product, process, or service by trade name, trademark, manufacturer, or otherwise, does not necessarily constitute or imply its endorsement, recommendation, or favoring by the United States Government or any agency thereot. The views and opinions of aurhors expressed herein do not necessarily state or reflect those of the United States Government or any agency thereof. 


\title{
AN INVESTIGATION OF SCRAMMING OF THE OUTER SHUTDOWN RODS OF THE ANS WITH NO REVERSAL OF FLOW IN THE MANIFOLD INLET LINES
}

\author{
Katarina Morsk \\ The Royal Institute \\ Stockholm, Sweden
}

Date Published: October 1992

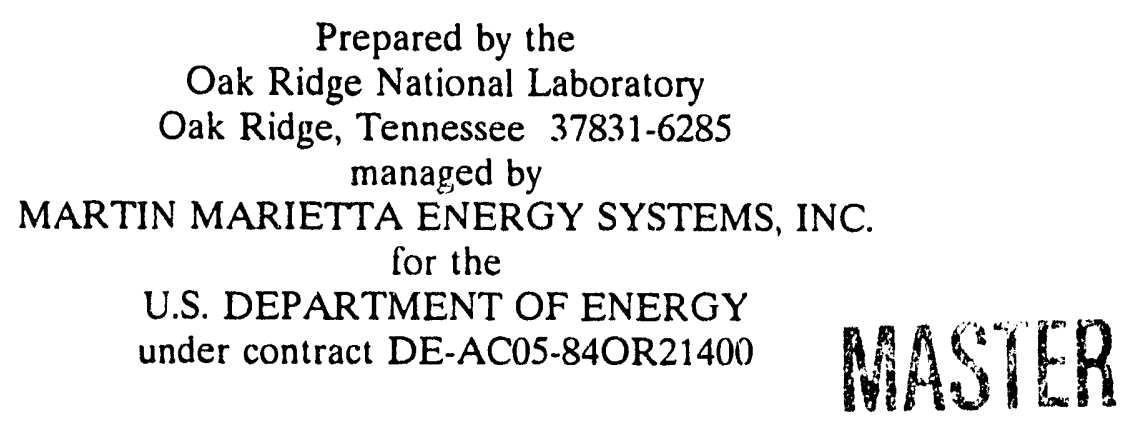




\section{TABLE OF CONTENTS}

\section{Page}

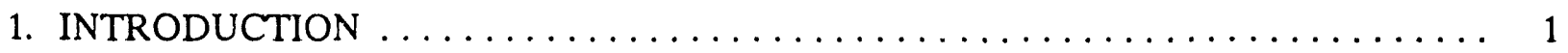

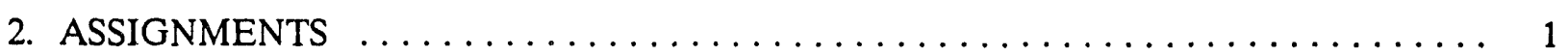

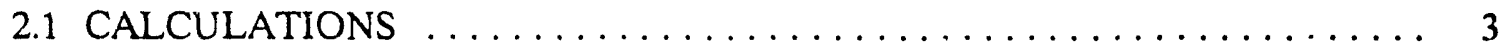

3. OUTER SHUTDOWN (CONTROL) RODS $\ldots \ldots \ldots \ldots \ldots \ldots \ldots \ldots \ldots \ldots$

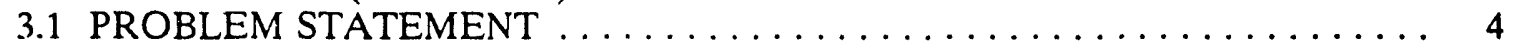

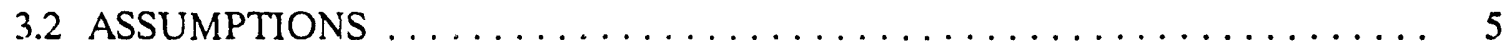

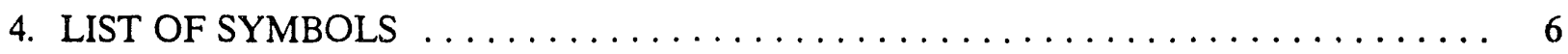

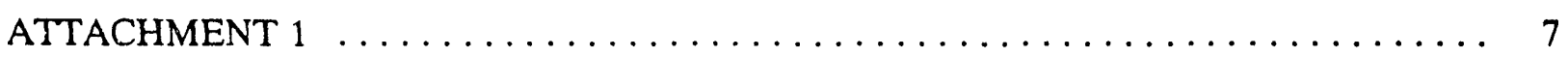

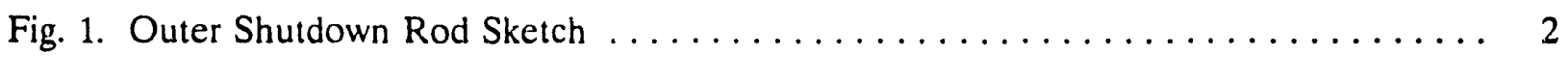

Table 1. Comparison of Scram Times with Design Parameters ................ 19 


\section{INTRODUCTION}

Katarina Morsk, a student at The Royal Institute of Technology in Stockholm, Sweden, worked at Oak Ridge National Laboratory (ORNL) for eight weeks in the summer of 1992. She will receive a master's degree in mechanical engineering, with a focus on nuclear technology, which made the summer job relevant to her studies.

Before graduate school, she worked at a Swedish nuclear power plant with a boiling water reactor, in operation since 1985 . That experience was beneficial in her work at ORNL and in understanding the basic principles of a nuclear reactor. Ste worked with P. S. Litherland, H. R. Payne, and G. L. Yoder. Her report is given below.

\section{ASSIGNMENTS}

In working with hydraulics and flow calculations, assignments during the eight weeks were to do calculations and calculation checks on the outer shutdown system, consisting of eight shutdown rods located on the outside of the core. The function of the system is to scram the reactor, or to break the chain reaction of the fission process. The shutdown rods are clad with a neutronabsorbing material (i.e., hafnium) to achieve scram.

During normal operation, the outer shutdown rods (Fig. 1) are in a nonscram, withdrawn position. This means that they are not close enough to the core to absorb a significant number of the neutrons that cause the fission process. In the case of a malfunction or an emergency, the outer control rods are moved to a position near the core.

The outer shutdown system is a shutdown function only and is not used for power control. Another system called the inner control rod system controls the power level and also scrams the reactor when needed. It operates similar to the outer shutdown system when the reactor is scrammed, but it is located inside the core. These two systems work independently of each other and use different principles.

The outer shutdown system is operated with the use of springs and hydraulics. During normal operation, a constant flow of heavy water is circulated through the reflector vessel. A part of this flow provides a pressure high enough to keep the rods in their withdrawn or upper position, a nonscram status. If any signs of abnormal operation occur, the valves in the hydraulic system cut off the flow, and the springs push the rods into the scram position, stopping 


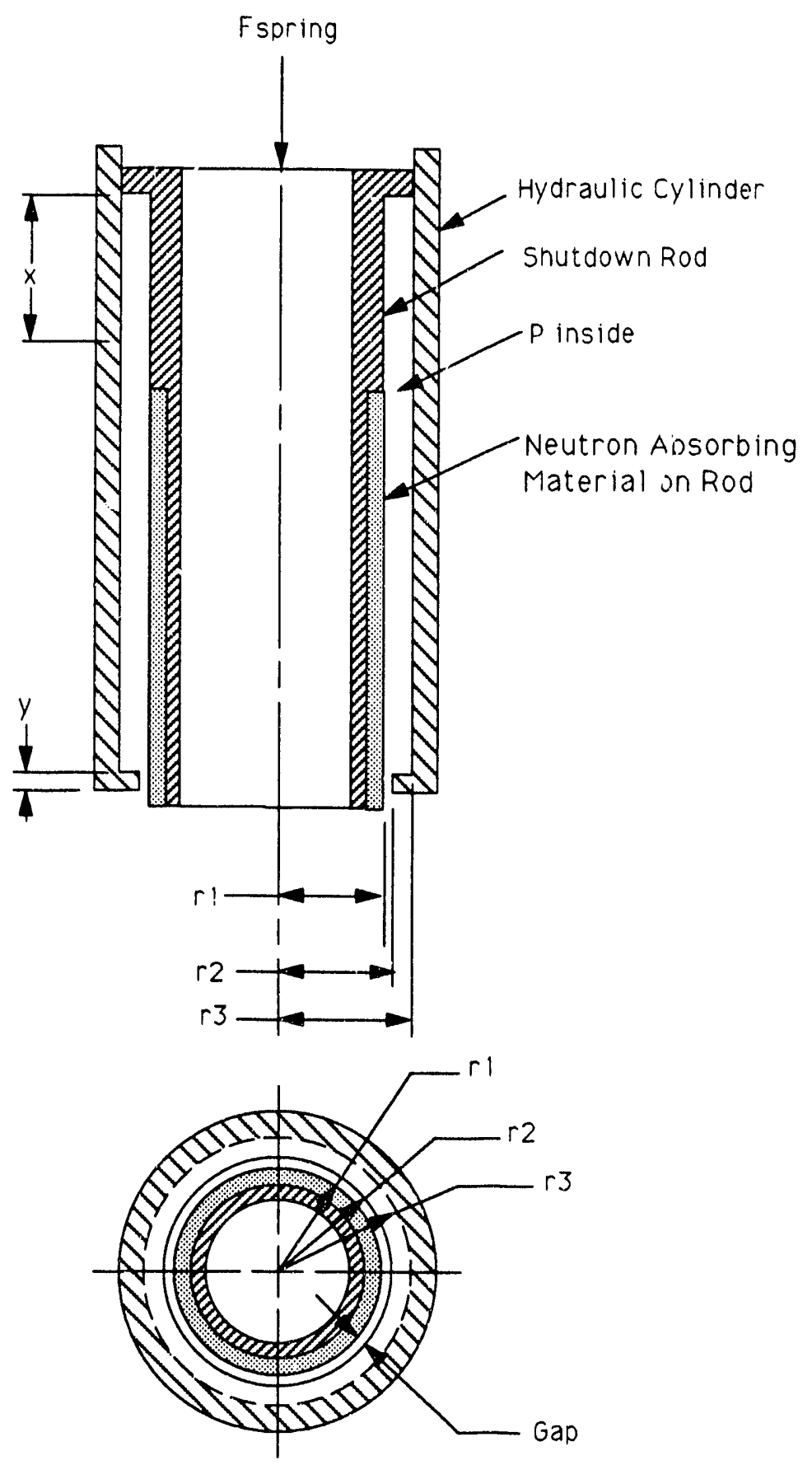

Fig. 1. Outer Shutdown Rod Sketch 
the chain reaction. Once the flow is restarted, the rods can be withdrawn to the nonscram position.

\subsection{CALCULATIONS}

My first task was to check calculations in which H. R. Payne had calculated the mass of the outer control rod, the scram spring data, and the hydraulic pressure to hold the rods in the withdrawn position. Further, the calculations included a circumferential stress check on the hydraulic cylinders and a leakage calculation. All numbers used and obtained were based on the absorber material being hafnium, which is most likely not going to be the final choice. It is, however, very easy to redo the same calculations with slightly different numbers. The result of the check was finding a mathematical error in the calculation of the mass of the rod that led to correcting several numbers throughout the calculations.

The second, much larger task was to do a calculation on my own (Attachment 1). In the case of a malfunction of the flow/pressure relief valves, a calculation was needed to show that the scram time would not exceed the time allowed. This assumption means that the hydraulic flow is shut off, but the flow/pressure relief valves that connect the manifold inlet line to the reflector vessel do not open. In other words, all the heavy water displaced from the hydraulic cylinders must exit through the small annulus at the lower end of the hydraulic cylinders. It is assumed that there is no leakage at the top of these cylinders. This makes it a conservative calculation, a socalled "worst case" scenario.

I tried to determine the scram time based on different values of the rod insertion length $(x)$ and the outside radius of the annulus ( $r 2)$. Calculating the pressure drop through the annulu: was the next step, accomplished with the aid of a CRANE Technical Paper' and G. L. Yode. In order to do this, I needed the values of the different velocities through the annulus that could be calculated by using the different values of $r 2$ and the maximum allowed insertion time. Plain mechanics would then allow me to get the effective force pushing the rod into the scram position, the rate of acceleration, and the actual scram time ( $\left.t_{\text {pushdown }}\right)$.

\footnotetext{
${ }^{1}$ Flow of Fluids through Valves, Fittings, and Pipe, Technical Paper No. 410, Crane Co., New York, 1978.
} 
After looking at the values from all angles, a decision was made to do it in a different manner. First of all, we settled for one rod insertion length. Secondly, we decided to consider four different scram times for the rod insertion. The other assumptions were the same as before. Like the first calculations, the velocity of the heavy water through the annulus during the scram and the corresponding pressure drop was calculated. Through a balance of forces, the compressed spring force was calculated, and this value was used to determine the pressure required to compress the spring during normal operation. Here, we came to the conclusion to use the larger value of $r 2$, that is $r 2=42.881 \mathrm{~mm}$. Using the four time allowances, the pressure needed to compress the spring was calculated in each case. Finally, the leakage flow rate through the annulus during normal operation was calculated.

As the numbers show, the leakage is quite high. Some flow of water is needed, however, to cool the shutdown rods in their withdrawn position. These calculations have rot yet been made, but they are not expected to be as high as these flow rates. These calculations are conservative. They are also based on mean values that might be different from the real case. To do the calculations, MathCad computer software was used on a Macintosh SE. H. R. Payne checked my calculation.

\section{OUTER SHUTDOWN (CONTROL) RODS}

\subsection{PROBLEM STATEMENT}

A pressure relief valve is provided in each of the two $D_{2} \mathrm{O}$ supply lines to the outer shutdown rods, and they are located in the reactor pool on top of the reflector vessel. In the event of a malfunction of both of these valves (no displacement of fluid from the control rod cylinders through them by way of the manifold inlet lines), part of the fluid inside the control rod cylinders must be displaced through the annular gap at the lower rod guide as the rod is inserted for the scram. This gap is provided to permit coolant flow downward around the lower end of the rod during normal operation. Verification is needed to insure that the scram time will not exceed the maximum allowed as the fluid is displaced through the annulus. The scram time involves signal processing time, solenoid valve closure time, time for the velocity of the fluid in the manifold inlet lines to be reduced to zero, and the response time for the spring-loaded rod to be inserted the required distance. 
These calculations are made to assist in determining an acceptable scram response time in this scenario. Four response times (Table 1) are considered for the rod insertion. Calculations are made to show the pressure in the cylinders during a scram, the spring force required to scram under these conditions, and the operating pressure required to compress the spring and the leakage flow (rod coolant) through the annulus into the reflector tank. These calculations are made for $150 \mathrm{~mm}$ of control rod insertion, and, initially, two thicknesses of the coolant flow annulus at the lower rod guide are considered.

\subsection{ASSUMPTIONS}

The solenoid-operated shutoff valves (located outside the reactor pool) stop the flow in both lines to the outer shutdown rods, but both pressure relief valves on top of the reflector vessel fail to operate. This prohibits reversing the flow in the inlet lines. Because there is high velocity coolant flow through the annulus around the rod at the lower end of the hydraulic cylinders, the pressure in the cylinders is immediately reduced to the pressure resulting from the spring-driven piston displacing fluid through the thin anriulus as the rod scrams. Flow into the control rod cylinders stops immediately, and the fluid inside the cylinders that must be displaced as the rod is inserted will have to exit through the thin annulus. 


\section{LIST OF SYMBOLS}

= volume of $\mathbf{D}_{20}$ to be displaced out of control rod cylinder

r

= length of control rod insertion

y

= thickness of annulus between control rod guide and control rod, (leakage path)

$\mathbf{r}$

= outside radius of control rod

r2

= inside radius of rod guide (outside radius of annulus)

(radius of control rod plus gap)

$r 3$

= inside radius of control rod cylinder

Pru

= pressure in reflector vessel

\section{Fspring}

=initial force of scram spring

mrod

= mass of control rod

mtot

$=$ total mass of control rod and $0_{20}$ to be displaced

ค

=effective area of the control rod piston

$\mathbf{g}$

=gravitational constant

Pinside =pressure inside control rod cylinder (with no hydraulic

$$
\text { flow) }
$$

$K \quad$ =resistance coefficient through gap

h

=pressure drop through gap (in meters)

h

=pressure drop through gap (in Pascals)

v =velority of $0_{2} 0$ through gap 


\section{Known}

$$
\begin{aligned}
& x:=150 \cdot 10^{-3} \cdot m \quad \text { length of control rod insertion } \\
& y:=26.4 \cdot 10^{-3} \cdot m \\
& \text { r1 }:=42.5 \cdot 10^{-3} \cdot \mathrm{m} \\
& r 2:=\left[\begin{array}{l}
42.754 \cdot 10^{-3} \cdot \mathrm{m} \\
42.881 \cdot 10^{-3} \cdot \mathrm{m}
\end{array}\right] \text { with } \mathrm{r} 1 \text { this defines gap thickness } \\
& r 3:=50 \cdot 10^{-3} \cdot m \\
& g:=9.81 \cdot \frac{\mathrm{m}}{\mathrm{sec}^{2}} \\
& \operatorname{Prv}:=0.3 \cdot 10^{6} \cdot \mathrm{Pa} \\
& \operatorname{mrod}:=15^{\bullet} \mathrm{kg} \\
& \text { pD20: }=1078.2 \cdot \frac{\mathrm{kg}}{3} \\
& \text { VD2O }:=\pi \cdot\left[r 3^{2}-r 1^{2}\right] \cdot x \\
& \text { mtot }:=\operatorname{mrod}+(\rho D 20 \cdot V D 2 O) \\
& \text { mtot }=15.35249^{\cdot} \mathrm{kg} \quad \operatorname{rod} \operatorname{mass}+\mathrm{D}_{2} 0 \text { displaced } \\
& \text { at } \mathbf{8 0} \text { degrees Celcius }
\end{aligned}
$$



$A:=\pi \cdot\left[r 3^{2}-r 1^{2}\right]$
$A=0.00218 \cdot \mathrm{m}^{2}$

From CRANE Technical Paper Number 410 - Flow of Fluids, page 3-4, equation nr. 3-14 is used to calculate the pressure drop through the gap between the control rod guide and the rod.

$$
\begin{aligned}
& \frac{h L=K * U^{*} U}{2 * g} \\
& K 1 .:=0.5 \quad K 1: \text { pipe entrunce } \\
& \alpha:=\frac{r 2}{r 1} \\
& \beta \quad:=\frac{1}{\alpha} 0 \\
& \beta \quad:=\frac{1}{\alpha} \\
& 1 \\
& \alpha=\left[\begin{array}{l}
1.00598 \\
1.00896
\end{array}\right] \\
& \beta=\left[\begin{array}{l}
0.99406 \\
0.99111
\end{array}\right]
\end{aligned}
$$




$$
\begin{aligned}
& \theta:=\frac{90}{2} \cdot \operatorname{deg} \\
& \mathrm{K} 2:=\frac{0.5 \cdot\left[1-\beta_{0}^{2}\right] \cdot \sqrt{\sin (\theta)}}{\beta_{0}^{4}} \\
& \mathrm{~K} 2:=\frac{0.5 \cdot\left[1-\beta_{1}^{2}\right] \cdot \sqrt{\sin (\theta)}}{\beta_{1}^{4}} \\
& \mathrm{~K}_{0}=0.0051 \\
& \mathrm{~K} 2_{1}=0.00771
\end{aligned}
$$$$
\text { K2:sudden contraction of pipe }
$$$$
\mathrm{K} 3:=1.0
$$$$
\mathrm{K}:=\mathrm{K} 1+\mathrm{K} 2+\mathrm{K} 3
$$$$
K=\left[\begin{array}{r}
1.5051 \\
1.50771
\end{array}\right]
$$

$t:=70 \cdot 10^{-3} \cdot \mathrm{sec}$ 


$$
\begin{aligned}
& v_{0}:=x \cdot \frac{r 3^{2}-r 1^{2} 1}{r 2^{2}-r 1^{2} t} \\
& v_{1}:=x \cdot \frac{r 3^{2}-r 1^{2} 1}{r 2^{2}-r 1^{2} t}
\end{aligned}
$$

$$
v=\left[\begin{array}{l}
68.65114 \\
45.69935
\end{array}\right] \cdot \frac{\mathrm{m}}{\mathrm{sec}}
$$

$$
h_{0}:=k \cdot \frac{v_{0}^{2}}{2 \cdot g}
$$

$$
\begin{aligned}
& h_{1}:=k \cdot \frac{v^{2}}{2 \cdot g} \\
& \Delta h:=h \cdot \rho D 20 \cdot g
\end{aligned}
$$

$$
\begin{aligned}
& \Delta h=\left[\begin{array}{c}
3.82411 \cdot 10^{6} \\
1.69749 \cdot 10^{6}
\end{array}\right] \cdot \mathrm{Pa} \\
& \text { Pinside }:=\Delta h+\operatorname{Prv}
\end{aligned}
$$$$
\text { Pinside }=\left[\begin{array}{c}
4.12411 \cdot 10^{6} \\
1.99749 \cdot 10^{6}
\end{array}\right] \cdot \mathrm{Pa}
$$

\section{Velocity of $D_{20}$ through gap}

Head in meters across the gap

\section{Converting meters to Pascal}

Mean pressure to displice $0_{2} 0$ during time allowed for scram 
With the balance of forces working in different directions, the following equation is used:

Fspring $+\operatorname{mrod} * g=\operatorname{mrod} * 6 * g+(P i n s i d e-P r u) * h$

$$
\begin{aligned}
& \text { Fspring }:=\operatorname{mrod} \cdot 5 \cdot g+(\text { Pinside }- \text { Prv }) \cdot A \quad \text { Initia! spring force to } \\
& \text { Fspring }=\left[\begin{array}{c}
9.07032 \cdot 10^{3} \\
4.43539-10^{3}
\end{array}\right] \cdot \text { newton } \\
& \text { Pspring : }=\frac{\text { Fspring }}{A} \\
& \text { Pspring }=\left[\begin{array}{l}
4.16169 \cdot 10^{6} \\
2.03507 \cdot 10^{6}
\end{array}\right] \cdot \mathrm{Pa}
\end{aligned}
$$


Using a different time allowance and the larger value of $r$, the following results ore recieved:

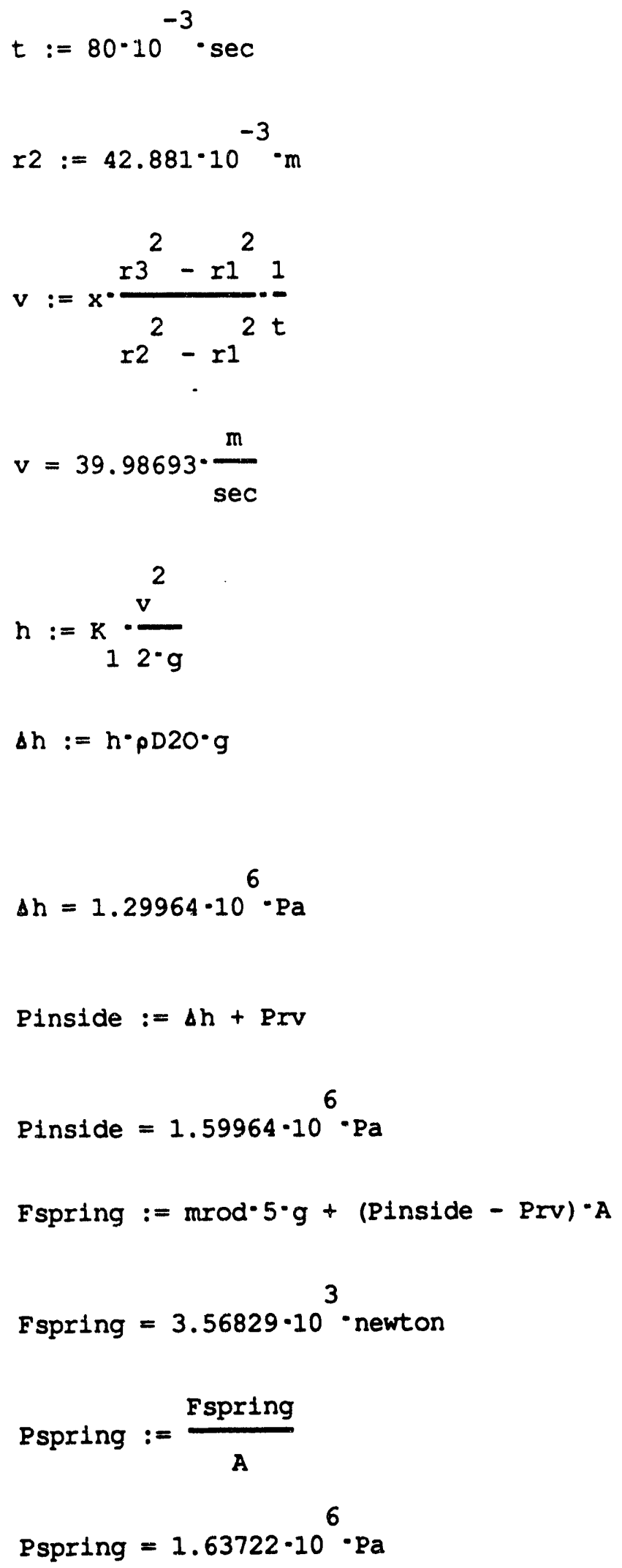


Using yet another time allowance, the results obtained are:

$$
\begin{aligned}
& t:=90 \cdot 10^{-3} \cdot \sec \\
& r 2:=42.881 \cdot 10^{-3} \cdot \mathrm{m} \\
& v:=x \cdot \frac{r 3^{2}-r 1^{2} 1}{r 2^{2}-r 1^{2} t} \\
& v=35.54394 \cdot \frac{\mathrm{m}}{\mathrm{sec}} \\
& \mathrm{h}:=\mathrm{k} \cdot \frac{\mathrm{v}^{2}}{2 \cdot \mathrm{g}} \\
& \Delta h:=h * p D 20 \cdot g
\end{aligned}
$$

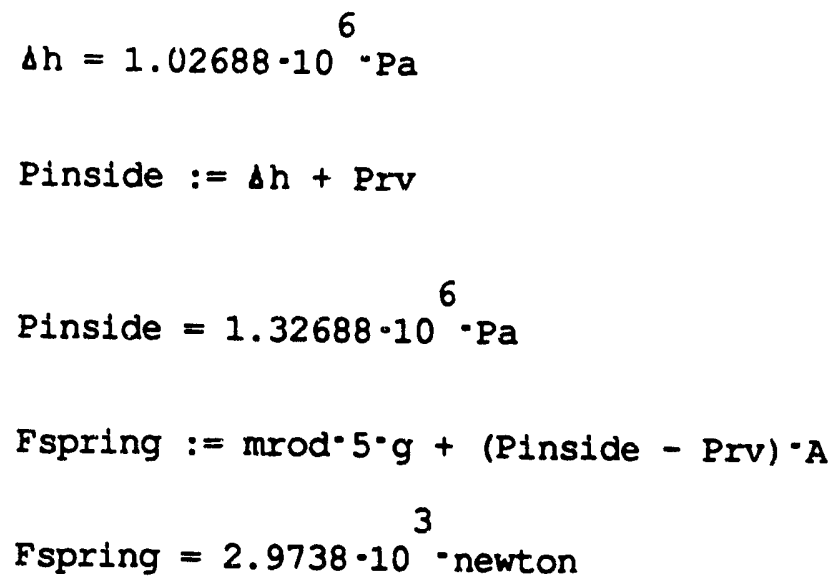




$$
\begin{aligned}
& t:=100 \cdot 10^{-3} \cdot \sec \\
& r 2:=42.881 \cdot 10^{-3} \cdot \mathrm{m} \\
& v:=x \cdot \frac{r 3^{2}-r 1^{2} 1}{r 2^{2}-r 1^{2} t} \\
& v=31.98954 \cdots \frac{\mathrm{m}}{\mathrm{sec}} \\
& \mathrm{h}:=\mathrm{k} \cdot \frac{\mathrm{v}^{2}}{2 \cdot \mathrm{g}} \\
& \Delta h:=h \cdot p D 20 \cdot g
\end{aligned}
$$

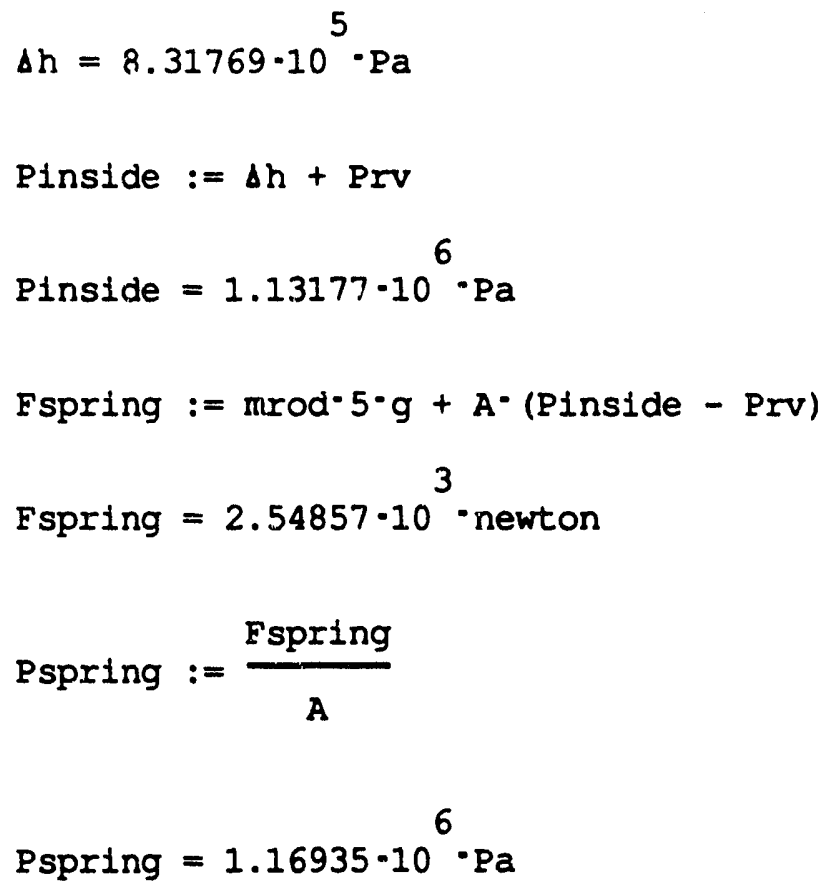


The values above are used to calculate the flow rate of the leakage of $\mathrm{D}_{20}$ through the gap during normal operation, that is when the rods are in the withdrawn position, for the four scram times considered.

$t=70^{*} 10^{\wedge}-3 \mathrm{sec}$

$r 2=42.881 * 10^{\wedge}-3 m$

$$
\begin{aligned}
& \text { Pspring }:=2.035 \cdot 10^{6} \cdot \mathrm{Pa} \\
& \mathrm{h}:=\frac{\text { Pspring }}{\rho \mathrm{D} 2 \mathrm{C} \cdot \mathrm{g}} \quad \text { Head in meters ocross the gap } \\
& \mathrm{h}=192.39602 \cdot \mathrm{m}
\end{aligned}
$$$$
\begin{aligned}
& v:=\sqrt{2 \cdot g \cdot \frac{r_{1}}{k}}{ }_{1} \\
& v=50.03672 \cdot \frac{\mathrm{m}}{\mathrm{sec}}
\end{aligned}
$$$$
\text { Agap }:=\pi \cdot\left[\mathrm{r2}^{2}-\mathrm{rl}^{2}\right]
$$$$
\text { Agap }=1.02197 \cdot 10^{-4} \cdot \mathrm{m}^{2}
$$$$
Q:=v \cdot \text { Agap }
$$$$
\text { Leakage (rod coolant) flow rate }
$$

$$
\begin{aligned}
& Q=0.00511 \cdot \frac{\mathrm{m}^{3}}{\mathrm{sec}} \\
& Q=81.05187 \cdot \frac{\mathrm{gal}}{\mathrm{min}}
\end{aligned}
$$




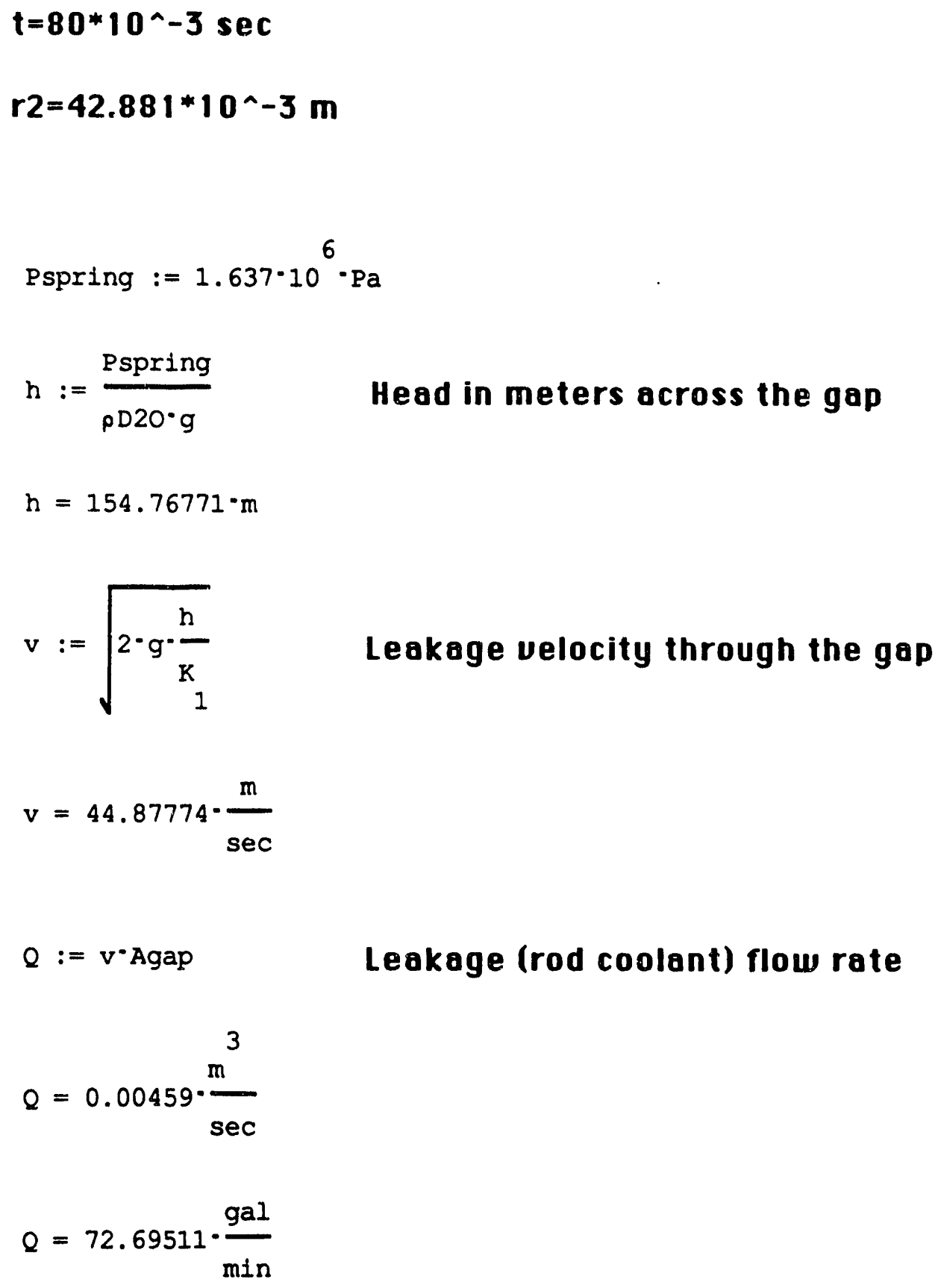




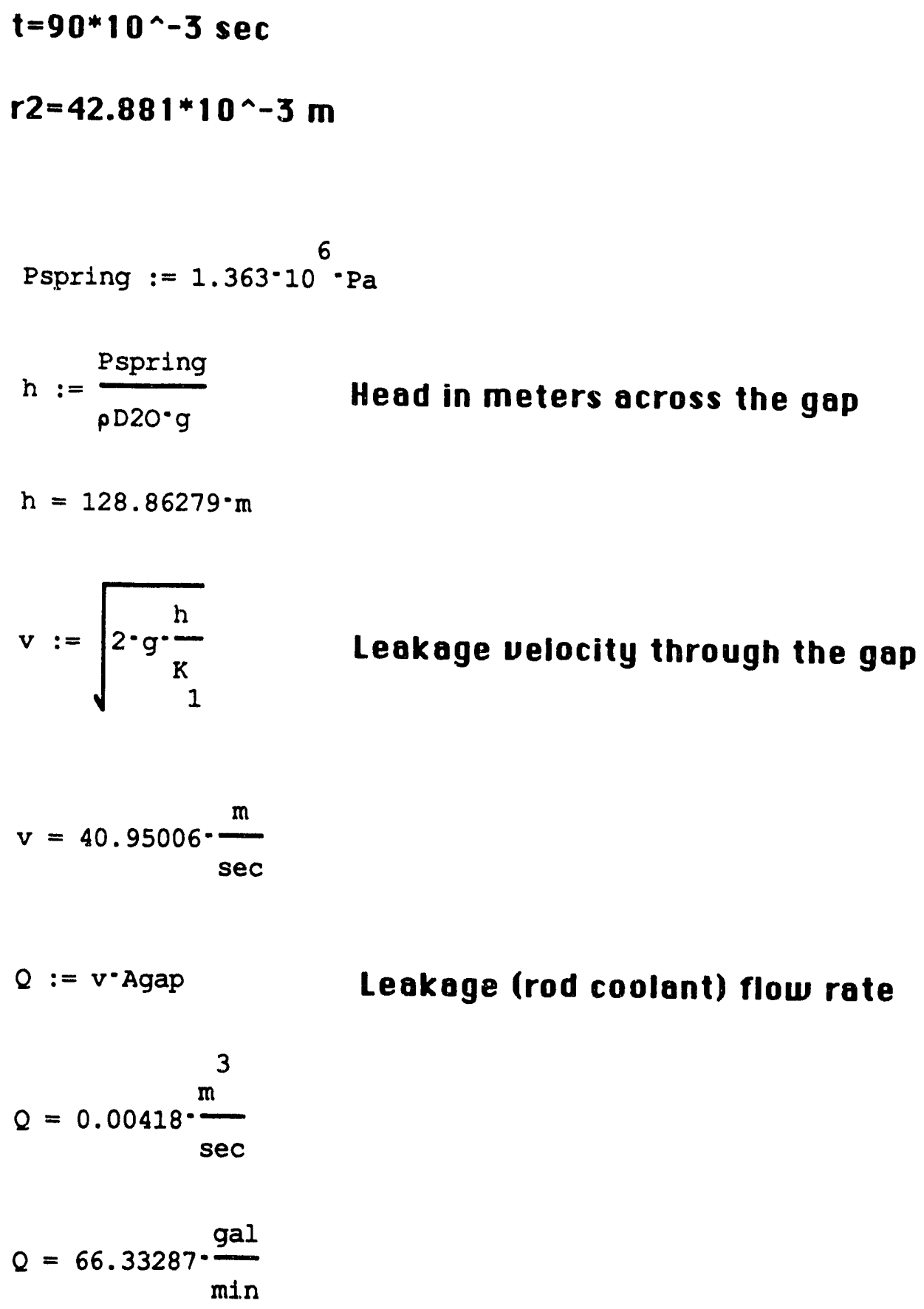




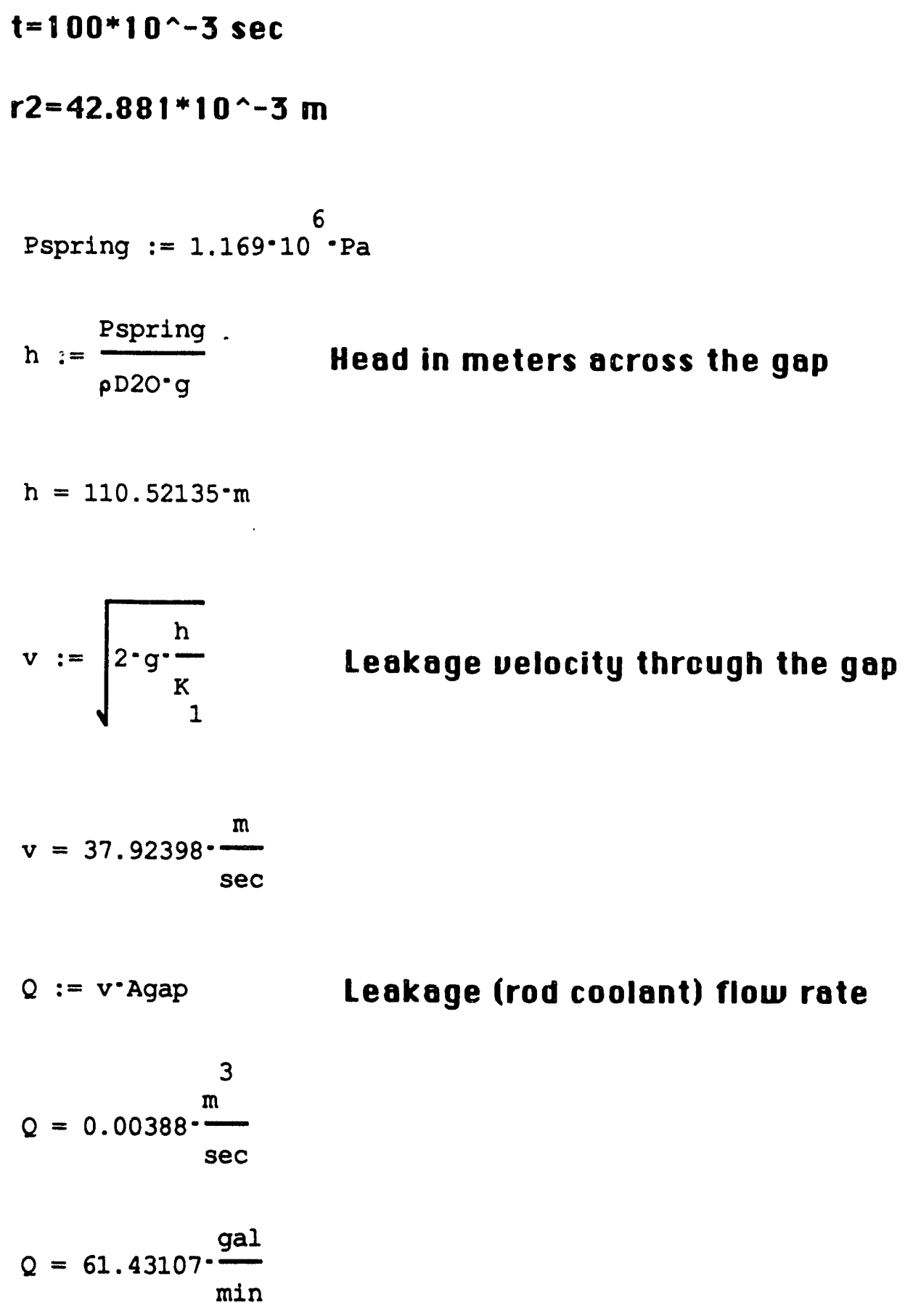




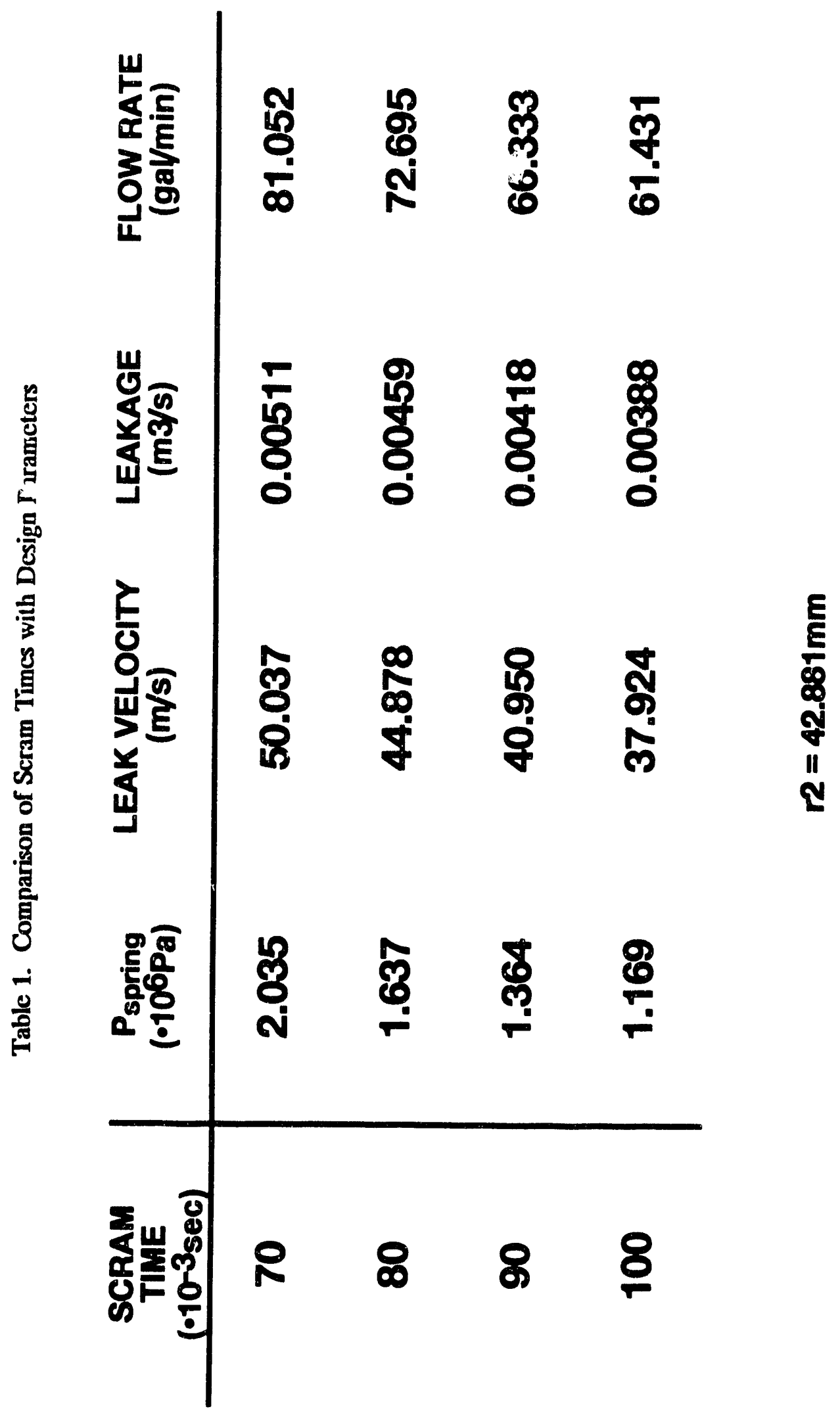




\section{Internal Distribution}

1. C. W. Alexander

2. D. J. Alexander

3. R. R. Allen

4. E. E. Alston

5. J. L. Anderson

6. B. R. Appleton

7. R. E. Battle

8. R. S. Booth

9. W. W. Bowman

10. R. A. Brown

11. G. J. Bunick

12. J. H. Campbell (5)

13. P. F. Cento

14. N. C. J. Chen

15. K. K Chipley

16. J. E. Cleaves

17. J. T. Cleveland

18. G. L. Copeland

19. B. L. Corbett

20. J. R. Dixon

21. F. F. Dyer

22. D. K. Felde

23. R. E. Fenstermaker

24. M. L. Gildner

25. H. A. Glovier

26. R. M. Harrington

27. J. B. Hayter

28. S. E. Holliman

29. M. M. Houser

30. D. T. Ingersoll

31. J. A. Johnson

32. R. L. Johnson (4)

33. M. Kaminaga

34. R. A. Lillie

35. P. S. Litherland

36. A. T. Lucas

37. J. A. March-Leuba

38. B. S. Maxon

39. G. T. Mays
40. S. V. McGrath

41. T. J. McManamy

42. G. R. McNutt

43. B. H. Montgomery

44. R. M. Moon

45. D. G. Morris

46. R. E. Pawel

47. H. R. Payne

48. H. S. Payne

49. F. J. Peretz

50. C. C. Queen

51. S. Raman

52. C. T. Ramsey

53. J. S. Rayside

54. J. P. Renier

55. J. B. Roberto

56. T. L. Ryan

57. D. L. Selby

58. H. B. Shapira

59. M. Siman-Tov

60. B. R. Smith

61. R. P. Taleyarkhan

62. D. W. Thiesen

63. S. R. Tompkins

64. P. B. Thompson

65. K. R. Thoms

66. D. B. Trauger

67. B. D. Warnick

68. C. D. West

69. J. L. Westbrook

70. D. M. Williams

71. B. A. Worley

72. G. T. Yahr

73. G. L. Yoder

74. A. Zucker

75. ORNL Patent Office

76. Central Research Library

77. Y-12 Technical Library

78-79. Laboratory Records

80. Laboratory Records (RC)

\section{External Distribution}

81. R. Awan, U.S. Department of Energy, NE-473, Washington, DC 20585.

82. C. L. Christen, DRS/Hundley Kling Gmitter, FEDC, MS-8218, P. O. Box 2009, Oak Ridge, TN 37831-8218. 
83. R. A. Edlund, U.S. Department of Energy, Oak Ridge Field Office, FEDC, MS-8218, P. O. Box 2009, Oak Ridge, TN 37831-8218.

84. R. R. Fullwood, Brookhaven National Laboratory, Upton, NY 11973.

85. W. R. Gambill, Route 5, Box 220, Clinton, TN 37716.

86. B. Gupta, AECL Technologies, 1155 Metcalfe Street, 2nd Floor, Montreal, Quebec, Canada H3B 2V6.

87. A. F. Henry, Professor, Department of Nuclear Engineering, Massachusetts Institute of Technology, 77 Massachusetts Avenue, Cambridge, MA 02139.

88. R. A. Hunter, Director, Office of Facilities, Fuel Cycle, and Test Programs, Nuclear Energy Division, U.S. Department of Energy, NE-47, Washington, DC 20585.

89. L. C. Ianniello, Acting Associate Director, Office of Basic Energy Sciences, Office of Energy Research, U. S. Department of Energy, ER-10, Washington, DC 20585.

90. T. L. Kerlin, University of Tennessee, College of Engineering, 315 Pasqua Engineering Building, Knoxville, TN 37996-2300.

91. J. A. Lake, Manager, Nuclear Engineering and Reactor Design, Idaho National Engineering Laboratory, P. O. Box 1625, Idaho Falls, ID 83415.

92. W. F. Manning, U.S. Department of Energy, Oak Ridge Field Office, FEDC, MS-8218, P. O. Box 2009, Oak Ridge, TN 37831-8218.

93-94. W. E. Meek, Project Manager, Gilbert/Commonwealth, Inc., P. O. Box 1498, Reading, PA 19603.

95-97. K. Morsk, Ostermalmsg. 67, 11450 Stockholm, Sweden.

98. W. T. Oosterhuis, Materials Sciences Division, Office of Basic Energy Sciences, Office of Energy Research, U.S. Department of Energy, ER-132, Washington, DC 20585.

99. H. Preble, Research and Test Reactor Fuel Elements, Babcock and Wilcox Co., P. O. Box 785, Lynchburg, VA 24505.

100. J. M. Ryskamp, Idaho National Engineering Laboratory, P. O. Box 1625, Idaho Falls, ID 83415.

101. J. L. Snelgrove, Coordinator, Engineering Applications, RERTR Program, Argonne National Laboratory, 9700 South Cass Avenue, Argonne, IL 60439.

102. I. Thomas, Director, Materials Science Division, Office of Energy Research, U.S. Department of Energy, ER-13, Washington, D.C. 20585.

103. J. M. Warren, Gilbert/Commonwealth, Inc., 1055 Commerce Park Drive, Suite 200, Oak Ridge, TN 37830.

104. D. K. Wilfert, Energy Programs, U. S. Department of Energy, Oak Ridge Field Office, FEDC, MS-8218, P. O.Box 2009, Oak Ridge, TN 37831-8218.

105. P. W. Winkler, Air Products and Chemicals, Inc., 7201 Hamilton Boulevard, Allentown, PA 18195-1501.

106-117. Office of Scientific and Technical Information, P. O. Box 62, Oak Ridge, TN 37831.

118. Office of Assistant Manager, Energy Research and Development, P. O. Box 2001, Oak Ridge, Tn 37831-8600 

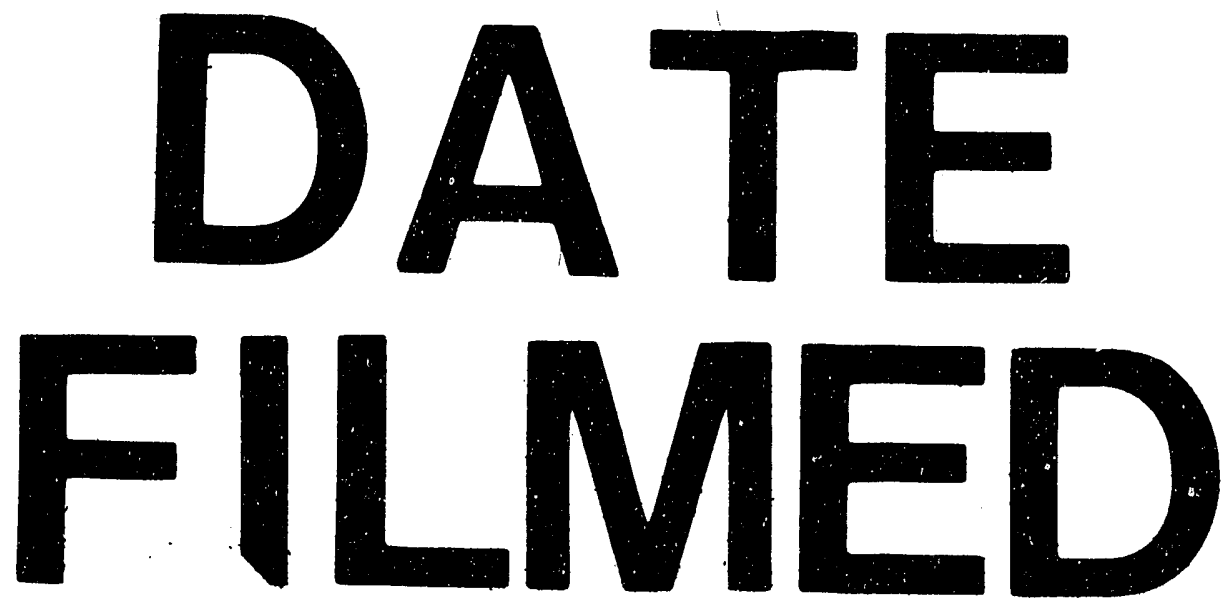

$12 / 18 / 92$ 